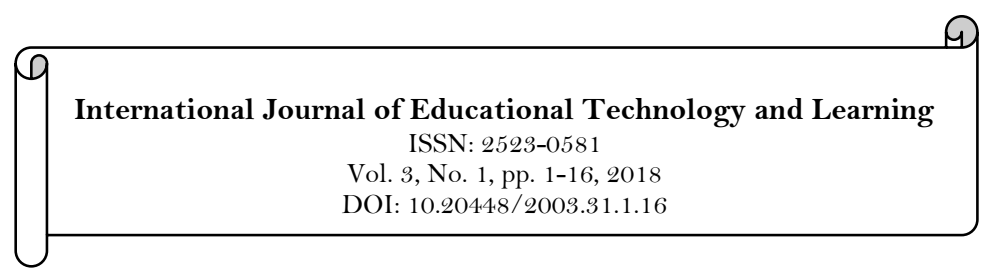

\title{
Pioneers in Unknown Territory: Teacher Perceptions and Use of Non-Conventional Instructional Tools
}

\author{
Louis S. Nadelson' ${ }^{2}$ \\ Stephanie M. Juth ${ }^{2}$ \\ Christina Hartman ${ }^{3}$ \\ Sam Gedeborg ${ }^{4}$ \\ Andrew Glaze ${ }^{5}$
}

- ${ }^{1}$ Colorado Mesa University Grand Junction, CO, USA.

Email:lonisnadelson@gmail.com

2,3,4,5 Emma Eccles Jones College of Education and Human Services Utah State University Logan, UT, USA.

\section{Abstract}

In an ongoing effort to understand teacher adoption of innovative instructional practices and their consideration of non-conventional tools for teaching and learning we collected survey data from over 300 teachers. From the 44 teachers who participated in our research we found a lack of alignment between teacher personal use of technology for teaching, high levels of teacher-centered use of technology and low levels of student-centered access to technology for learning, and need for instructional technology professional development that is different than what the teachers are receiving. Our discussion includes possible explanations, implications, and directions for future research.

\author{
Keywords: \\ Innovation \\ Instruction \\ Learning \\ Technology \\ Change \\ Student-centered. \\ Licensed: \\ This work is licensed under a \\ Creative Commons Attribution \\ 4.0 License. \\ Publisher: \\ Scientific Publishing Institute
}

\section{Introduction}

Access to modern instructional technology (e.g., desktop computers) is in its fourth decade and yet many of the schools that we work in or visit still look very much like they did 60 years ago, with students sitting in rows at desks, and the teacher standing in front of the room. The persistence of a historical model of education in a post-computer-age society suggests that there is a misalignment between teacher perceptions, knowledge, and use of instructional technology (non-conventional instructional tools) and their instructional practices and choices. We consider non-conventional instructional tools to include, but not limited to, the computer hardware and software that is not commonly or traditionally used for teaching and learning.

The disconnect between the readily accessible technology for teaching and learning and the persistence of traditional educational models, led us to wonder what is the current state of teacher perceptions, student engagement, preparation, and use of non-conventional instructional tools. Give the rapidly evolving landscape of technology in society, as well as the potential shifts of expectations and uses of technology and other tools in schools, there is an ongoing need to explore the various facets of teacher non-conventional tool use, preparation, and perceptions in K-12 education. Further, our research attends to the call by Lawless and Pellegrino (2007) to gain a deeper understanding of how technology integration takes place in schools.

\subsection{Teachers' Beliefs, Propensity for Change, and Adoption of Educational Innovations}

Models of teacher change may be useful for examining the processes involved in teacher change and the professional development designed to promote shifts in teacher instructional practices and curricular choices (Guskey, 2002). However, examining teacher change also involves consideration of the complex interaction among personal, institutional, and societal influences (Blanchard, Southerland, \& Granger, 2009; Briscoe, 1991; Guskey, 2002; Nadelson, Briggs, Hammons, Bubak, \& Sass, 2012; Nadelson, Seifert, \& Sias, 2015). Thus, when examining conditions that involve teacher change one must consider an array of factors that might be influencing teacher practice. We contend that the influences on teacher change are most appropriately considered from the perspective of the teacher, as we recognize it is teacher perceptions of 
affordances and barriers that are most likely to influence their practice and consideration of innovative instructional approaches and creative curricular choices.

The complexity of teacher change is evident when considering their adoption or resistance to adopting educational innovations, such as the use of technology for teaching (Palak \& Walls, 2009). Even when immersed in teaching environments that include expectations for innovative teaching practices, many teachers may continue to maintain traditional practices such as teacher-centered learning (Palak \& Walls, 2009).

In contrast, those teachers who have shifted to more student-centered use of technology, tend to focus on student needs and how their learning might be enhanced using technology (Ottenbreit-Leftwich, Glazewski, Newby, \& Ertmer, 2010). Regardless, the integration of technology does not necessarily promote constructivists instructional practices (Windschitl \& Sahl, 2002). Thus, when considering teacher change and adoption of education innovations and the use of non-conventional tools, it is critical to examine how teachers engage their students in the use of technology (student-centered use) in comparison to teacher use of technology for instruction (teacher-centered use).

Innovation in the classroom can take any number of forms. Scott and Bruce (1994) define innovation as the "production and adoption of useful ideas and idea implementation," while also "[adapting] the products or processes from outside an organization" (p. 581). Thus, teachers who have a greater propensity to try innovative curricular and instructional approaches are more likely to embrace and use technology and other nontraditional tools in new and novel ways (Nadelson, Sias, \& Seifert, 2016; Wozney, Venkatesh, \& Abrami, 2006).

Given the significant role schools play during the formative years of students, demonstrating an openness towards innovation and by extension access to and use of non-conventional tools, is critical to developing similar innovative attitudes in students. Kanter (2000) describes "kaleidoscope thinking," the creative element in the innovation process which involves the development of new views and ways of thinking through rearrangement of existing knowledge and ways of thinking. For example, kaleidoscope thinking takes place when teachers adapt their use of and interactions with non-conventional tools to integrate novel uses of the tools in their instruction and for their students' learning. Thurlings, Evers, and Vermeulen (2015) argue that innovation is an important instructional component, which cannot be ignored, “... schools should set a good example and act as a starting point for more innovative behavior of our citizens so that society can stay competitive" (Thurlings et al., 2015). Thus, the conceptual framework for our research involves consideration of teacher change and adoption of innovation as we examined their perceptions, practices and knowledge of using non-conventional instructional tools for learning and instruction.

Teachers' lack of engagement with non-conventional tools often arises from a complex set of beliefs on the role of the teacher, the structure of education, and the ways students learn (Ertmer \& Ottenbreit-Leftwich, 2010). In general, teachers who hold more traditional beliefs about teaching and learning tend to implement "low-level" or traditional technology integration (Browns et al., 2007) whereas teachers who hold a more constructive belief system are more likely to implement "high - level" technology which is student-centered (Ertmer \& Ottenbreit-Leftwich, 2010). In order for teachers to integrate non-conventional tools into their curriculum, the integration of the tools must have some degree of alignment with their current beliefs (Ertmer \& Ottenbreit-Leftwich, 2010; Hughes, 2005). Thus, teachers who are considering adopting a nonconventional tool into their regular classroom routine need to believe that the integration will be worthwhile in order for the process of integration to be successful (Abrami, Poulsen, \& Chambers, 2004). Educators tend to value what enables them to meet their perceptions of what student need to be learn, and, as a result, they are more likely to integrate non-conventional tools and methods if they believe they are working towards meaningful educational learning outcomes (Ertmer \& Ottenbreit-Leftwich, 2010).

Conversely, Gregoire (2003) notes that teacher discomfort or negative feelings surrounding an adoption of new practices might lead to more thoughtful processing of the conditions. To some teachers, the idea of embracing cell phones as instructional tools could seem impossible and unlikely to succeed, thereby creating a self-fulfilling prophecy. Alternatively, feelings of hesitancy towards non-conventional tools might lead to meaningful implementation particularly if combined with proper professional development.

Often, teacher's resistance to implement non-conventional tools stems from an educator's perceived competency with using the tools (Ertmer \& Ottenbreit-Leftwich, 2010; Lawless \& Pellegrino, 2007; Subramaniam, 2007). Although educators might perceive non-conventional tools to be helpful in allowing them to accomplish personal and professional tasks more efficiently, they often are reluctant to incorporate them into their lessons due to lack of training and knowledge (Ertmer \& Ottenbreit-Leftwich, 2010). Niess (2005) similarly observed that a basic teacher understanding of how to use technology was significantly related to its successful instructional integration. In order to improve teacher's competency in effectively implementing technology, teachers likely need professional development focused on technological pedagogical content knowledge, pedagogical technology integration knowledge, and relevant knowledge of information and communication technologies (Ertmer \& Ottenbreit-Leftwich, 2010).

Moreover, content knowledge has a significant impact on teachers' beliefs and capacity for change in instructional practices (Borko \& Putnam, 1995). We have (Nadelson et al., 2012) observed a relationship between a teachers' content knowledge and their effectiveness, comfort, confidence in their content area. Niess 
(2005) also found that a strong foundation in content knowledge helps teachers to strategically integrate technology into their curriculum.

Teacher confidence and perceived value of technology profoundly influence their instructional technology integration (Wozney et al., 2006). To effectively encourage teachers to utilize non-conventional tools, professional development time and effort must be devoted to increase educator's confidence, content area knowledge, and the efficacy of using these tools to meet student-learning outcomes. Therefore, there is warrant to examine the level to which teachers feel comfortable using a wide range of non-conventional tools as a potential proxy for explaining levels of use and perceptions of value of the tools.

\subsection{Teacher Practice and Use of Instructional Tools}

While the applicable and available technologies and digital information for teaching and learning has advanced substantially over the last 20 years, many teachers' practice seems to be relatively unaltered by the development (Hirumi, 2002; Warschauer \& Ware, 2008). The lack of change may be associated with teacher perceptions of how school should take place and how learning most effectively happens, which reflects the potential relationship between constructivist practices, personal computer use, and classroom technology use (Rakes, Fields, \& Cox, 2006). The potential association between teacher philosophy of learning and their use of technology provides justification for continuing to monitor their use of technology from both teacher and student centered perspectives. We can use their perspectives as indicators of practice, as well as proxies, for propensity for change and innovation adoption. Other indicators of propensity, such as perceptions of constructivist learning may not be useful, as teachers tend to indicate they hold perceptions of student centered practices (such as constructivism) but in reality tend to engage in teacher-centered curriculum and instruction (Cuban, Kirkpatrick, \& Peck, 2001). Thus, the potential misalignment between students' needs, teacher perceptions, and teacher practice (Baylor \& Ritchie, 2002; Ertmer, 1999; Nadelson et al., 2013) provides justification for focusing on teacher perception, practice, and knowledge related to the use of technology as indicators of their educational philosophy and propensity to engage in educational innovations.

Teacher use of instructional technology is likely to be associated with their experience with teaching. Although new teachers report higher levels of comfort with the use of technology, more experienced teachers used instructional technology more often for instruction or to engage students in learning (Russell, Bebell, O'Dwyer, \& O'Connor, 2003). Thus, professional experience appears to be associated with the likelihood that an instructor adopts educational innovations such as utilizing technology into the classroom (Nadelson et al., 2015) even though a younger generation might be more comfortable with said technology. Yet, (Roblyer, McDaniel, Webb, Herman, \& Witty, 2010) report that teachers were more likely to use more traditional technologies, such as email, for professional communication rather than newer technologies, such as social media. These findings suggest that although teachers may be using some technology effectively, more research is needed to understand which types tools they are using and why.

Similarly, Burns-Sardone (2014) report that while pre-service teachers were comfortable with the concept of students engaging in bring-your-own device (BYOD) to the school for personal use during learning (e.g., personal smartphone, computer tablet), they often lacked knowledge of the how to effectively leverage the BYOD to enhance student learning and teaching effectiveness. Clearly, understanding how to use the technology is only one piece of the instructional equation; knowledge of how to implement the technology as part of instruction to improve learning is equally critical. Ertmer and Ottenbreit-Leftwich (2010) also argue that teachers need additional technological pedagogical content knowledge, pedagogical technology integration knowledge, and relevant knowledge of information and communication technologies to effectively use non-conventional tools in their classrooms. Consequently, there is justification for examining the nonconventional tools related professional development desires and experiences of teachers.

There is a paradox between the rapidly increasing access, availability, functionality, and integration of nontraditional tools into society and popular culture, and the associated access to the similar learning resources and information, and the recognition of many technologies as non-conventional instructional tools. Although several studies have documented the positive relationship between technology use and studentcentered learning (Ertmer \& Ottenbreit-Leftwich, 2010; Goldberg, Russell, \& Cook, 2003) analyses suggest teachers primarily utilize technology for administrative tasks and teacher-directed activities (Ertmer \& Ottenbreit-Leftwich, 2010). Teachers' most frequent use of technology is often related to day-to-day procedural needs, such as the creation of handouts and assignments, use of PowerPoint, or to engage students in drill and practice activities (Becker, 1999; Ertmer \& Ottenbreit-Leftwich, 2010).

The consideration integrating non-conventional tools for teaching and learning pushes educators to view curriculum content as evolving and potentially integrated (Coiro, Knobel, Lankshear, \& Leu, 2008). Teachers are beginning to utilize non-conventional tools such as blogs, wikis, graphic novels, social networking, anime, and fan fiction to meet the needs of an evolving global society (Black, 2008; Clark, 2014; Coiro et al., 2008). Unfortunately, in many classrooms appear to "still operate in a mindset rooted in the Industrial Revolution that is forged in physical space and organized around the production of goods" (Black, 2008). Contemporary students will inevitably enter a world where they must consume, distribute, and produce information utilizing a variety of texts, print documents, graphic arts, and post-typographic communications (Black, 2008; 
Lankshear \& Knobel, 2006). The need to prepare our students for a future of rapidly evolving uses and reliance on technology provide justification for examining teachers' perceptions, knowledge and preparation to use technology for teaching and learning.

\subsection{Professional Development on Technology Use}

Although the availability of non-conventional tools in classrooms is growing exponentially, common barriers for integrating innovation and technology include: lack of infrastructure, accessibility, knowledge, and professional development (Funkhouser \& Mouza, 2013; Groff \& Mouza, 2008; Hixon \& Buckenmeyer, 2009; Ryan \& Bagley, 2015). Many students and educators are comfortable in using technology for personal use; however, there appears to be a gap between personal use of the tools and integration of the tools to fulfill instructional objectives (Gumbo, Makgato, \& Helene, 2012; Lawless \& Pellegrino, 2007). Educators often acknowledge the underuse of technology in the classroom, citing reasons such as not being provided the time to learn how to use technology, lack of technical support, and lack of training and professional development (Fabry \& Higgs, 1997).

Both in-service and pre-service teachers often struggle with the integration of technology due to limited and inadequate professional development (Brinkerhoff, 2006; Levin \& Wadmany, 2008; Tondeur et al., 2012). In terms of teacher preparation, teacher candidates are typically inadequately prepared to implement technology and non-conventional tools into their instructional practices (Brown \& Warschauer, 2006; Ryan \& Bagley, 2015). Sadly, in-service teachers also lack training, as very little professional development is offered to include the new pedagogies in technology (Groff \& Mouza, 2008; Ryan \& Bagley, 2015). As a result, evidence suggests that non-conventional tools are poorly integrated into instructional activities, resulting in many educators reliance on tools which are outdated and do not meet the needs or interests of their students (Ertmer \& Ottenbreit-Leftwich, 2010; Funkhouser \& Mouza, 2013). More research is needed to assess the efficacy of professional development to ensure both in-service and pre-service teachers have the necessary skills and knowledge to embrace, adopt, and assimilate non-conventional tools into their instructional pedagogy (Gumbo et al., 2012; Lawless \& Pellegrino, 2007).

\subsection{Research Questions}

To assure our research aligned with our goals to explore K-12 teachers' knowledge, perceptions, and uses of non-conventional instructional tools we developed the following questions to guide our investigation:

1. What is the level of teachers' awareness of non-conventional instructional tools?

2. What non-conventional tools do teachers and students engage with and frequent is the use?

3. How are teachers and students using non-conventional tools?

4. What are teachers' perceptions of potential benefits and challenges of the instructional use of non-conventional tools?

5. What are teachers' level of preparation for and experience with using non-conventional tools for instruction?

\section{Method}

\subsection{Participants}

Our participants were the K-12 teachers working in a large school district in the western United States. We distributed invitations to participate in our research to about 300 teachers and had 44 participants fully complete our survey. The average age of the teachers was 40.05 years $(S D=10.07)$ and had taught for an average of 12.22 years $(S D=7.99)$. In responses to the highest attained degree 24 indicated that they held bachelor degrees, 19 indicated holding a master degrees and one held a doctorate degree. Eleven of the participants were male and 33 were female. The majority of the participants taught at the secondary level $(N$ $=41)$ and balance of the participants taught at the elementary level $(N=3)$. More than half of the participants $(N=29)$ belonged to one professional organization, with most indicating the organization as a local or state level educational association. The teachers had engaged in an average of 16.55 hours of professional development within their school districts $(S D=18.05)$ and an average of 17.29 hours of professional development outside their school districts $(S D=33.24)$.

\subsection{Measures}

Demographics. To assess the demographics of our participants we adopted and adapted items inferred from instruments that have been used in prior research. The instrument contained a combination of selected and free response items designed to collect an array of personal and professional characteristics.

Survey of teacher perceptions and use of non-conventional tools. We were unable to locate an extant instrument aligned with our research goal that effectively assessed K-12 teachers' perceptions and use of nonconventional instructional tools. Thus, we determined there was a need to create an instrument to gather the desired and appropriate data necessary to answer our research questions. We began our instrument development by identifying the areas of significant interest in our investigation and the alignment with our research questions. As a team we then constructed several items for each of our areas of interest. 
For our focus related to instructional use, we developed items such as, "I am open to the idea of using smartphones as instructional tools in my classroom" which was to be answered on a five-point Likert scale ranging from "Strongly Disagree" (1) to "Strongly Agree" (5). We included a ranking matrix for tool use for teaching and another for student use. We also included numerous free response items with prompts such as, "Are there any benefits for teachers from the tools listed above for instruction? Please name the tool and then explain the benefit."

Once completed and compiled, we took turns examining the items for relevancy and redundancy. Given the unique and exploratory nature of our research, we determined that establishing the validity of our measure was suitably handled among the five of us on the research team. Our final instrument contained 46 items spread across rating scales for knowledge and use of specific non-conventional tools, Likert scale items to assess perceptions of using non-conventional instructional tools, similar Likert-scale like items for assessing potential to use the tools, and free response items dispersed throughout.

\section{Results}

\subsection{Teacher Awareness of Non-Conventional Tools}

Our first research question asked, What is the level of teachers' awareness of non-conventional instructional tools? To answer this question we determined the mean response to our item measuring perceived knowledge level non-conventional tools which we found to be $5.80(S D=2.00)$ on a 10-point scale ranging from "no knowledge" (1) to "expert knowledge" (10), which we interpreted to be a moderate level of knowledge of nonconventional tools.

We continued our focus of teacher awareness of non-conventional tools by examining responses to our item asking them to respond as "yes" or "no" to their consideration of a list of tools as non-conventional see Figure 1. Our analysis revealed that the greatest percentages of teachers considered smartphones, video conferencing and social media as non-conventional tools, while the smallest percentage considered document cameras, PowerPoint, and spreadsheets to be non-conventional.

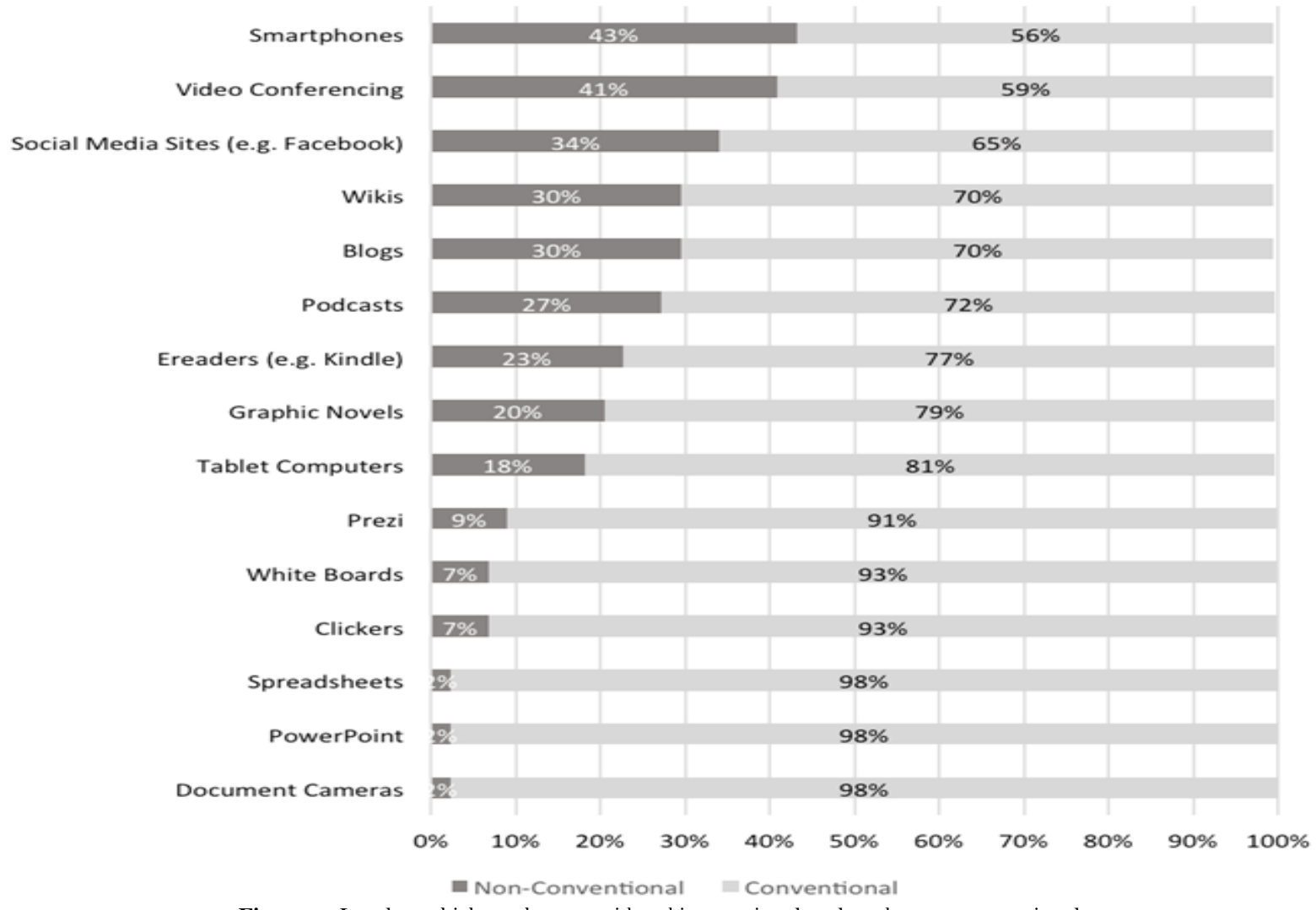

Figure-1. Level to which teachers considered instructional tools to be non-conventional.

Several teachers indicated that there is a need to expose students to tools that they would use in the future, indicating perceptions of the tools as potentially non-conventional. For example, one teacher wrote, "PowerPoint, Prezi, spreadsheets, podcasts, and video conference are all great tools to teach the students since they will probably use them again in future jobs." In contrast, another teacher shared that her students use personal whiteboards, which reflects a constrained perception of non-conventional tools: 
"We use personal student whiteboards nearly every day. This saves on paper but also gives me a quick response. I use it for math and language arts. I can see if letters and numbers are backwards. They are easy to take care of and use for teachers and students. They keep them in their desks and the markers in their pencil boxes."

\subsection{Tool Use}

Our second research question asked, What non-conventional tools do teachers and students engage with and how frequent is the use of the tools? To answer this question, we examined the responses regarding engagement and frequency of classroom of tools by themselves and by their students. We started by examining the responses to the item, "I currently use this tool as part of my teaching" which was associated with our list of instructional tools. We considered the percentage of "yes" responses see Figure 2 and found that the teachers most commonly use PowerPoint, whiteboards, and document cameras in their instruction, and least commonly use e-readers, video conferencing, and clickers. We found $59 \%$ of the teachers use smartphones in their instruction; however, in contrast, the teachers indicated that outside of their teaching they use phones between frequent $(4)$ and always $(5)$ on a five-point scale $(M=4.5, S D=.81)$. Our results indicate that personal use of the tools is inconsistent with professional use of the tools.

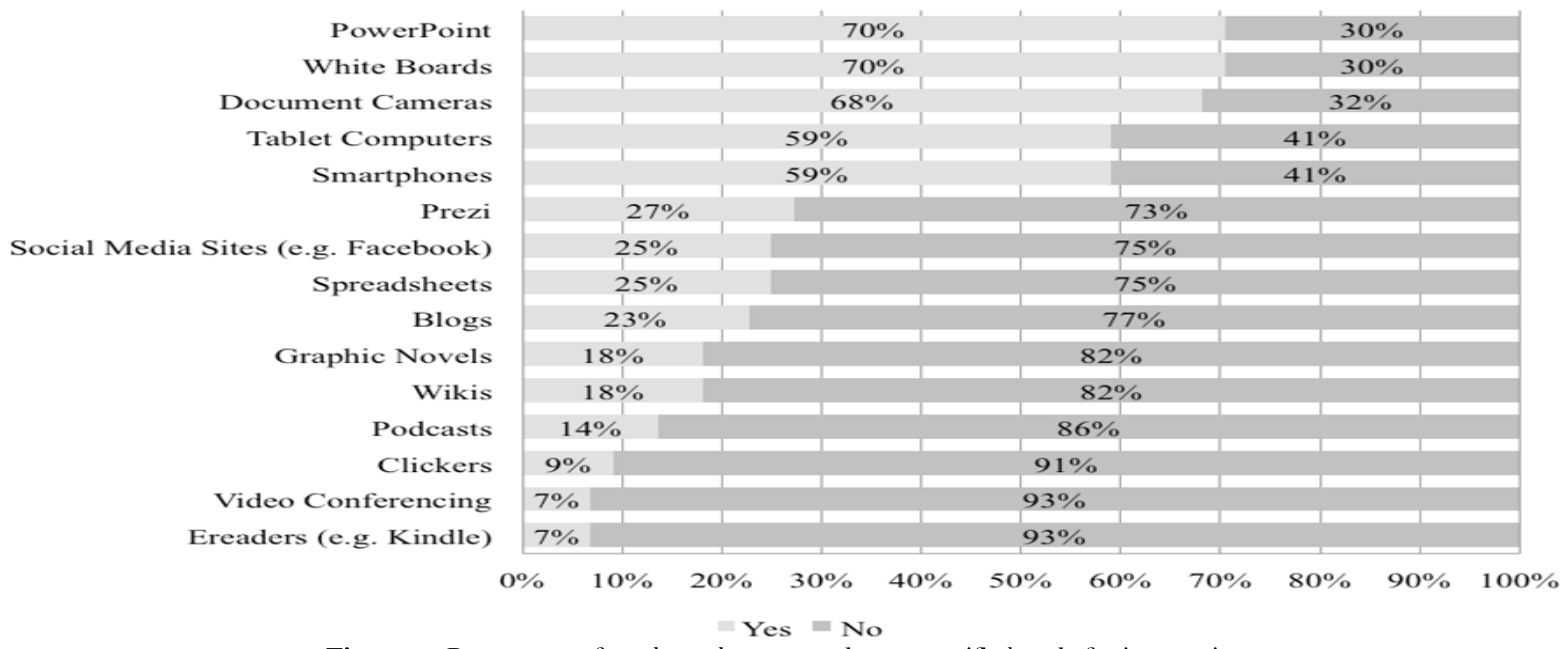

Figure-2. Percentage of teachers that currently use specified tools for instruction.

We followed our analysis of the teacher reported use with an examination of their reporting of how often they have their students use the tools for assignments see Figure 3. The participants responded to the student use of tools for assignment items on a 5-point Likert like scale ranging from "never" (1) to "always" (5). The top rated tools that the teachers indicated that they have students use in instruction were smartphones, tablet computers and PowerPoint which were between "seldom" and "sometimes" which suggests many tools were between "never" and "seldom" see Figure 3.

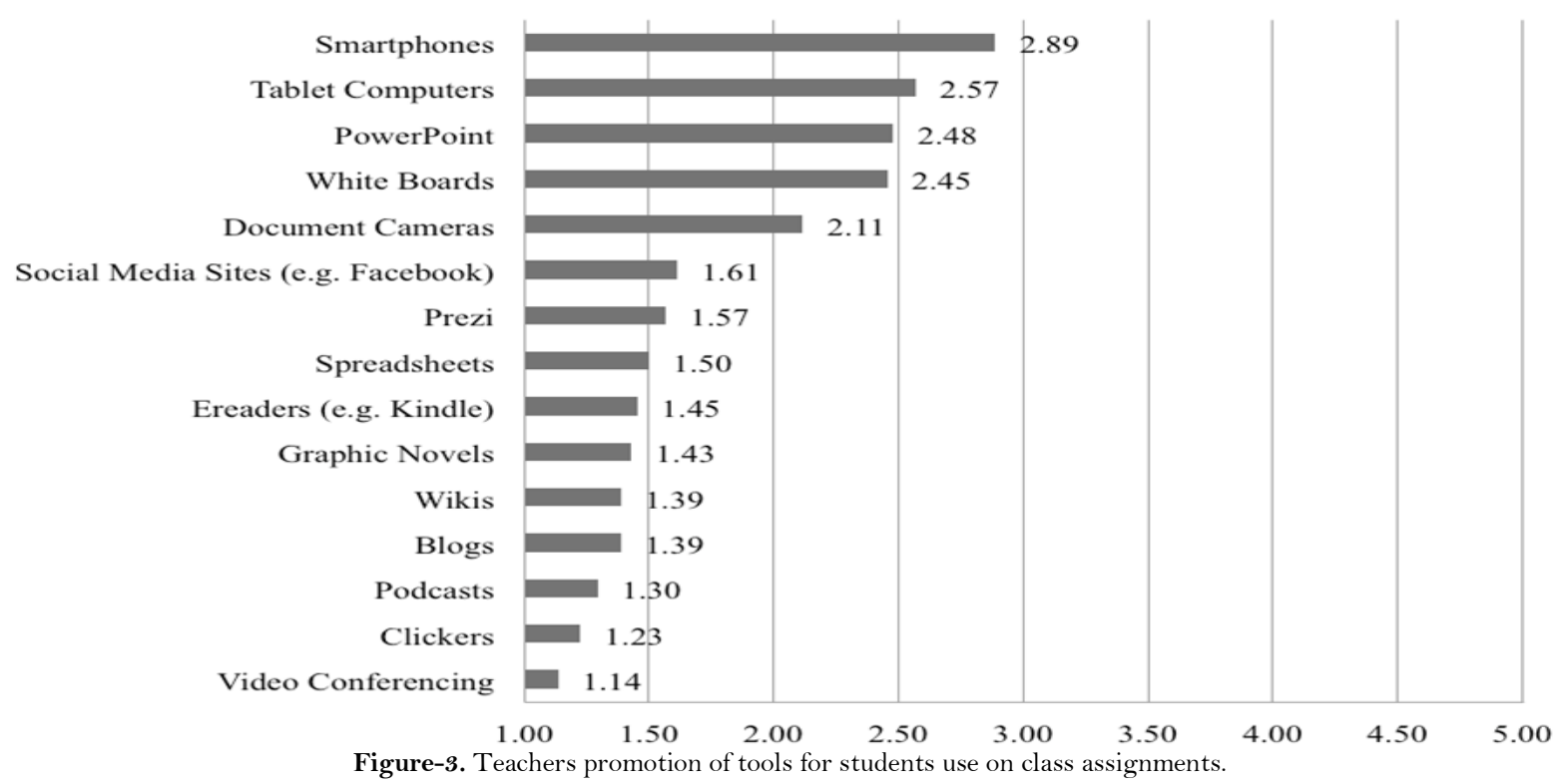


The responses to our items asking teachers how much they perceived that their students used tools daily (using a "yes" and "no" scale) revealed a substantial difference between smartphones and tablet computers and other tools see Figure 4. More than half of the participants indicated that students use tablet computers and smartphones daily. In contrast, tools like PowerPoint, document cameras, and whiteboards were used daily at substantially lower levels, with less than $15 \%$ of participants indicating that these tools are used by students daily.

Teachers acknowledged the use of a variety of non-conventional tools; however, many of tools frequently utilized in the classroom were teacher-centered. For example, one teacher noted, "PowerPoint is an easy way to provide a visual reminder during lecture. It's easy to save, easy to share (if students are absent) and easy to edit. It doesn't, however, easily get students involved and engaged." Another teacher stated, "Document cameras and white boards allow for papers to be used for immediate feedback, they allow teachers to make the text larger which helps more students to see it, and they allow teachers to save the work. Tablets allow teachers to use their main computer as the resource and access it through the tablet."

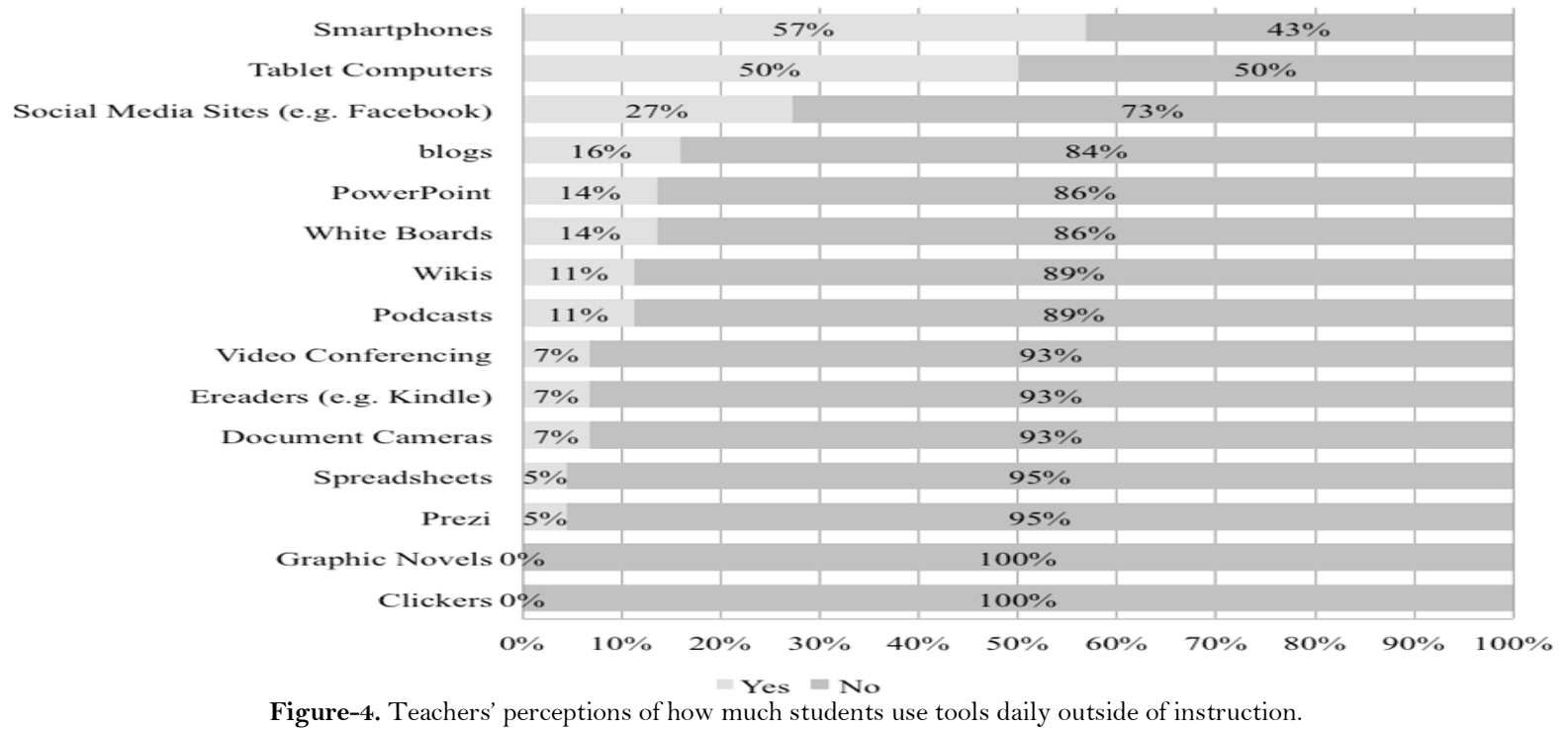

In the final stage of our tool use analysis, we examined the alignment between student use of tools for learning and teacher use of the same tools for instruction. We gathered these data using 5-point Likert scale items that used scales ranging from "never" (1) to "always" (5). Our analysis revealed that teachers used the technology more often than their students with the exception of smartphones see Figure 5.

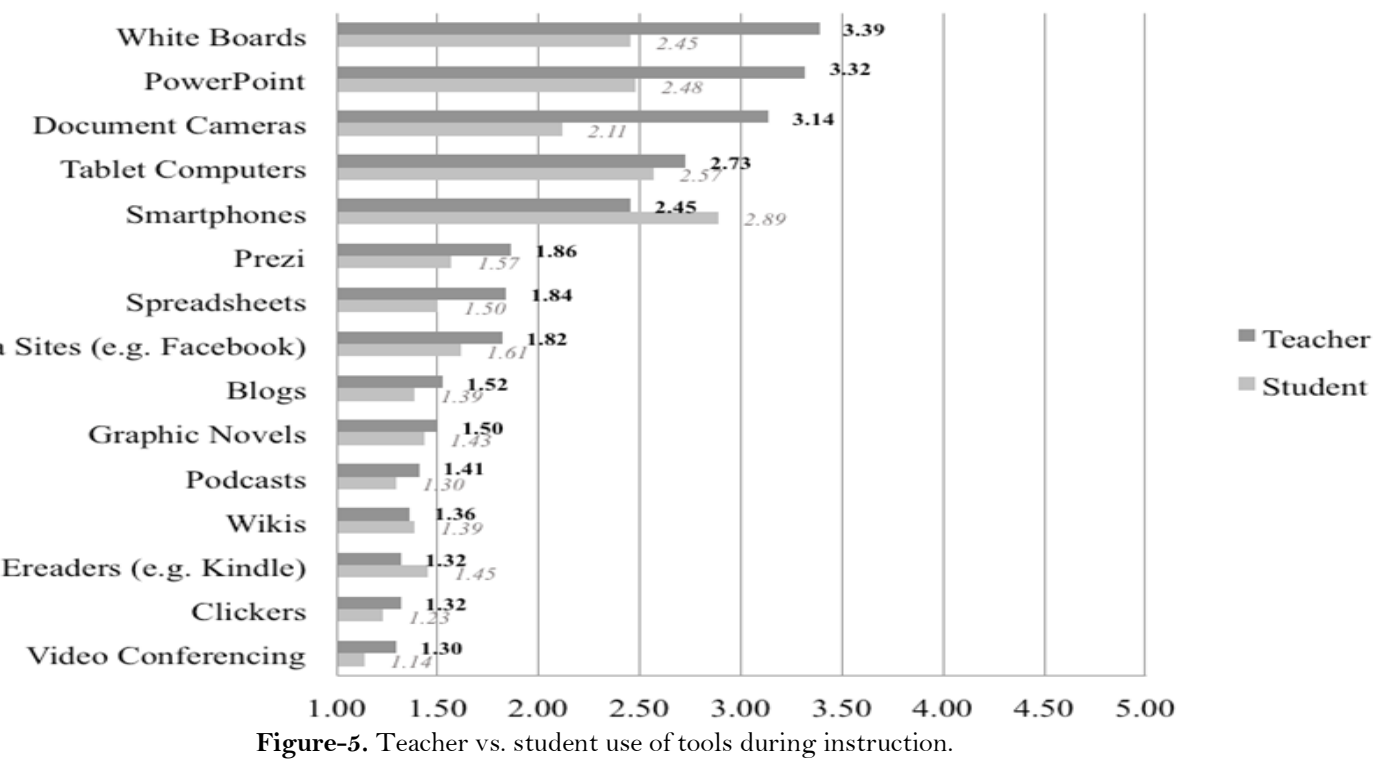


The most frequent student use of non-conventional tools was cell phones. Teachers noted cell phones were useful in terms of "quick and easy access to information," to remind students of upcoming assignments, and to use as calculators.

\subsection{How the Tools are used}

Our third research question asked, How are teachers and students using non-conventional tools? To answer this question, we examined the responses to our items focused on the application of the technology during instruction and learning. We started our analysis by examining the purposes teachers communicated for using smartphones or tablet computers in their classrooms. Our analysis revealed that teachers tend to use these devices as response systems and web browsers see Figure 6. Although the other category was the more frequent response, the entered applications varied widely making it difficult to discern notable trends. Teachers indicated that communication between students and as a reading device were nearly lowest in terms of expected use.

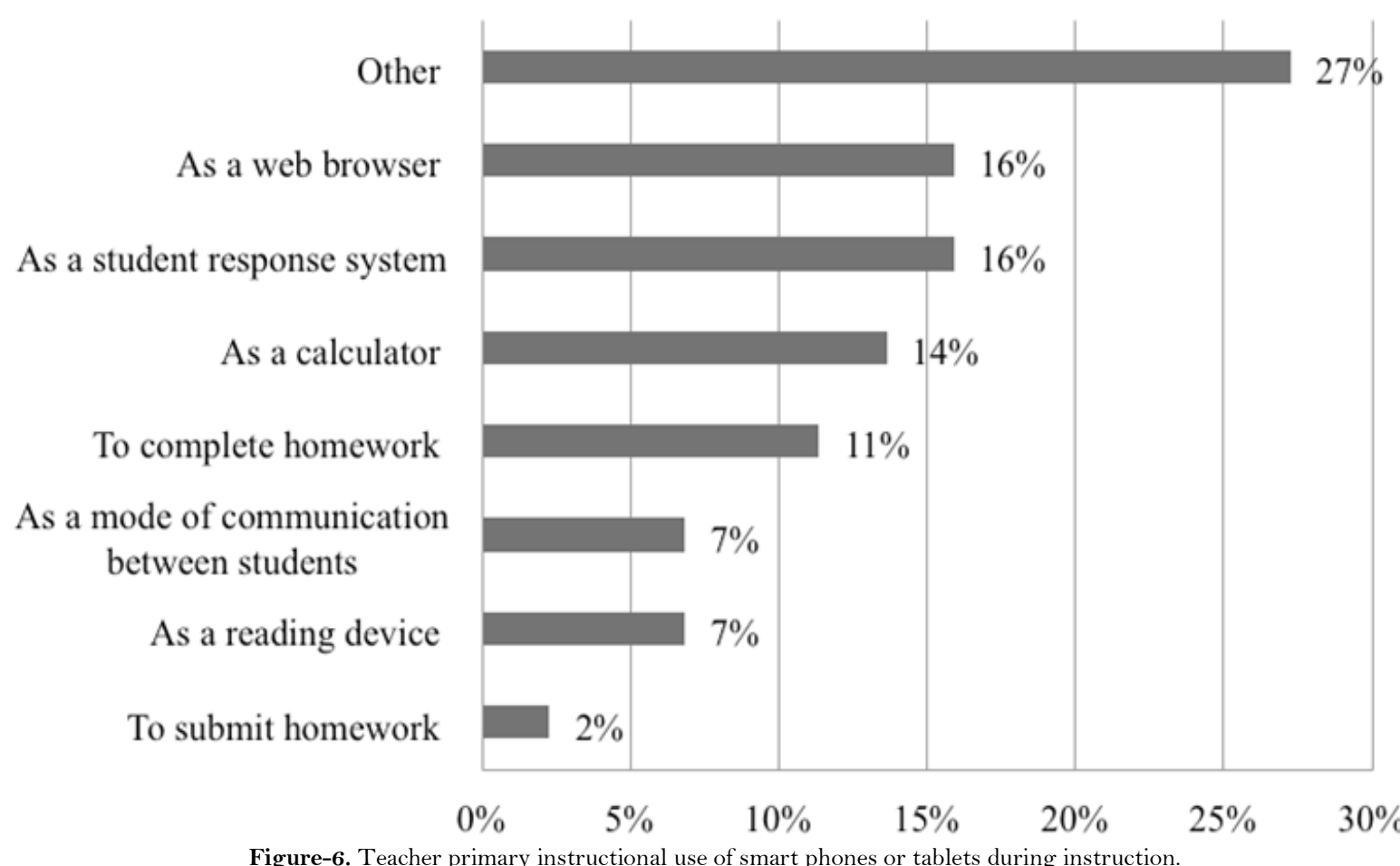

Teachers also stated technology can be a useful for reminding students of upcoming assignments, as one teacher explained, "Social media very useful for helping kids track/remember homework. Also makes it easy to post something quickly as a resource, like taking a photo of the notes for the day and posting it on social media account for all to access." Although, teachers often stated they used non-conventional tools for reminders of assignments, few teachers utilized these tools to have their students complete assignments.

We next examined the responses to our item asking the teachers if they used the tools in supplemental instruction. Our analysis revealed that about a third of the teachers indicated that they used tablet computers and PowerPoint in their students' supplemental instruction see Figure 7. However, the use of other tools for supplemental instruction dropped off rapidly indicating that the teachers consider few tools for students to use when developing and engaging in supplemental instruction. 


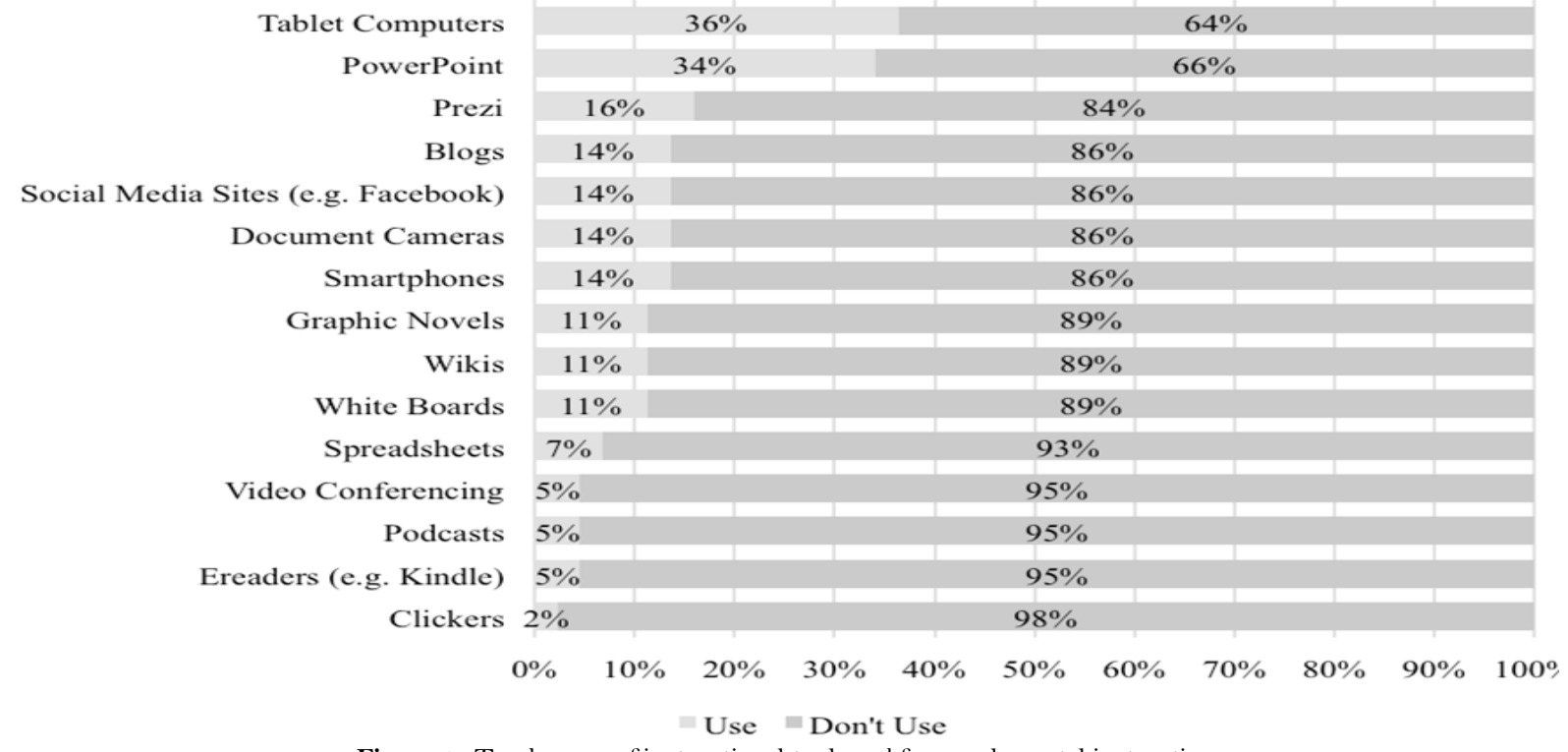

Figure-7. Teacher use of instructional tool used for supplemental instruction.

Next, we examined the participants' responses to our item asking if they expected their students to use the tools in their homework. About $23 \%$ of the teachers indicated expectations for students to use smartphones, tablet computers, and PowerPoint to complete homework assignments see Figure 8 . The consideration of other tools was between $0 \%$ and $11 \%$ suggesting a low expectation by teachers that students would use these tools outside the classroom.

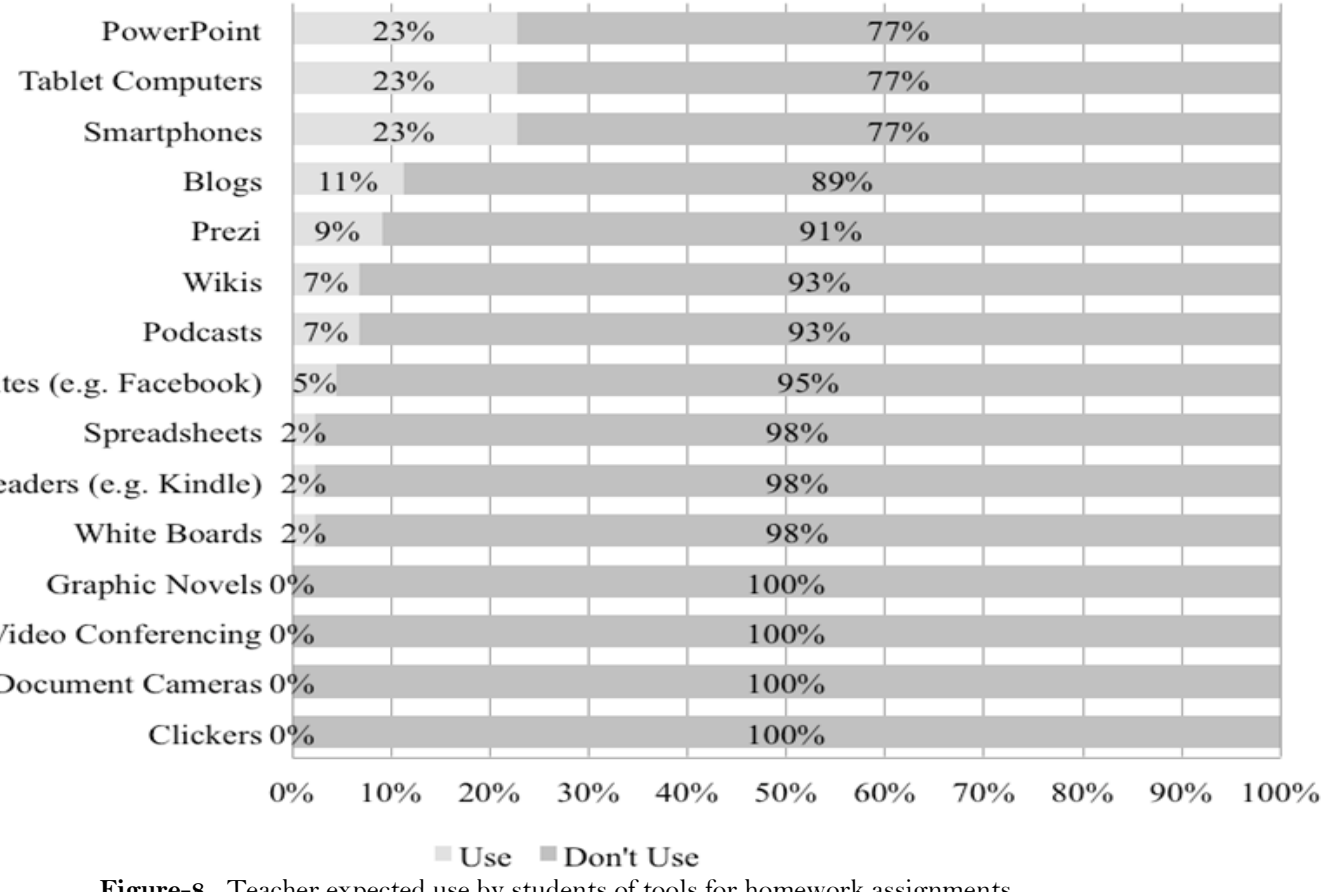

Figure-8. Teacher expected use by students of tools for homework assignments.

\subsection{Teacher Perceptions}

Our fourth research question asked, What are teachers' perceptions of the potential benefits and challenges of the instructional use of non-conventional tools? To answer this question, we examined the responses to our items regarding perceptions of the benefits and challenges of the instructional use of tools. The responses to our item that asked teachers about their openness to using smartphones as instructional tools in their classrooms revealed revealed that the teachers were close to "agree" (4) on the five-point scale Likert scale $(M=3.82 S D$ $=1.07$ ), which we interpreted as being fairly open to having students using smartphones in the classroom. We next examined the teachers' perceptions of the affordances that technology provide for their students which they responded to on a five point Likert scale ranging from strongly disagree (1) to strongly agree (5). We found that teachers tended disagree that student access to technology supports instruction, were about 
neutral on most other affordances such as providing rigor and adapting instruction, and varying instruction see Figure 9.

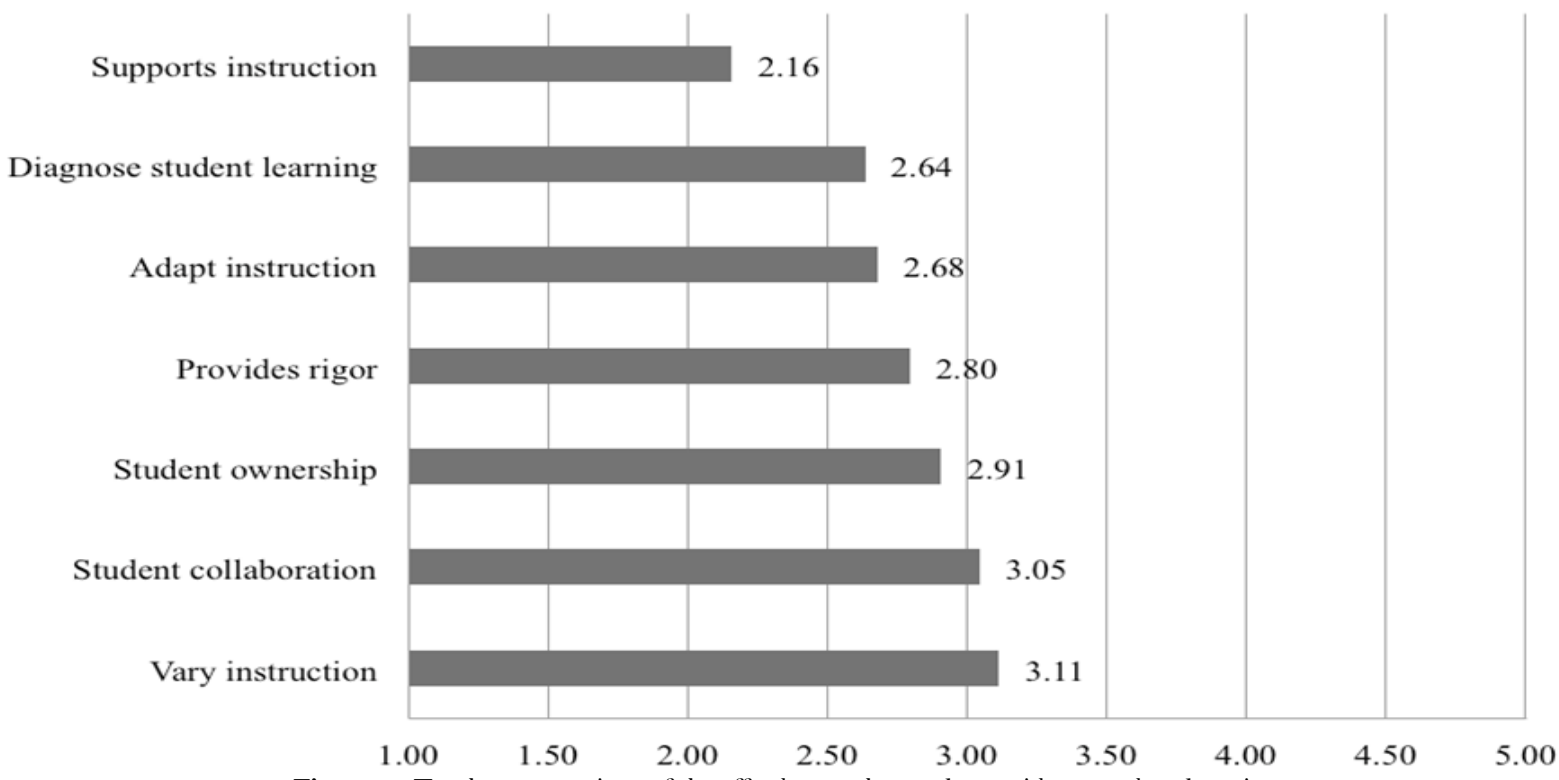

Figure-9. Teacher perceptions of the affordances that tools provide to student learning.

Some teachers shared that they perceived technology as beneficial to student engagement. As shared by one teacher, "I believe the primary benefit from using any of these tools is increased student engagement, with the added benefit in the cases of smartphones, tablets, and social media, of helping the students see the academic applications of things they are already using". Additionally, another teacher shared, "Phones, tablets, and the internet options help with student engagement, making classroom management easier. Students feel teachers understand them when they understand how the newer technology works and use them regularly."

We continued our exploration of teacher perceptions of the use of technology for learning by exploring the responses of the teachers to our items asking them to indicate whether or not a range of tools improve student engagement in learning. With the exception of tablet computers and smartphones, which where were nearly evenly split between "yes" and "no" responses, the teachers perceived that most technologies would not enhance student engagement in learning see Figure 10. According to our surveyed teachers, the use of nonconventional tools is not likely to enhance student engagement in learning.

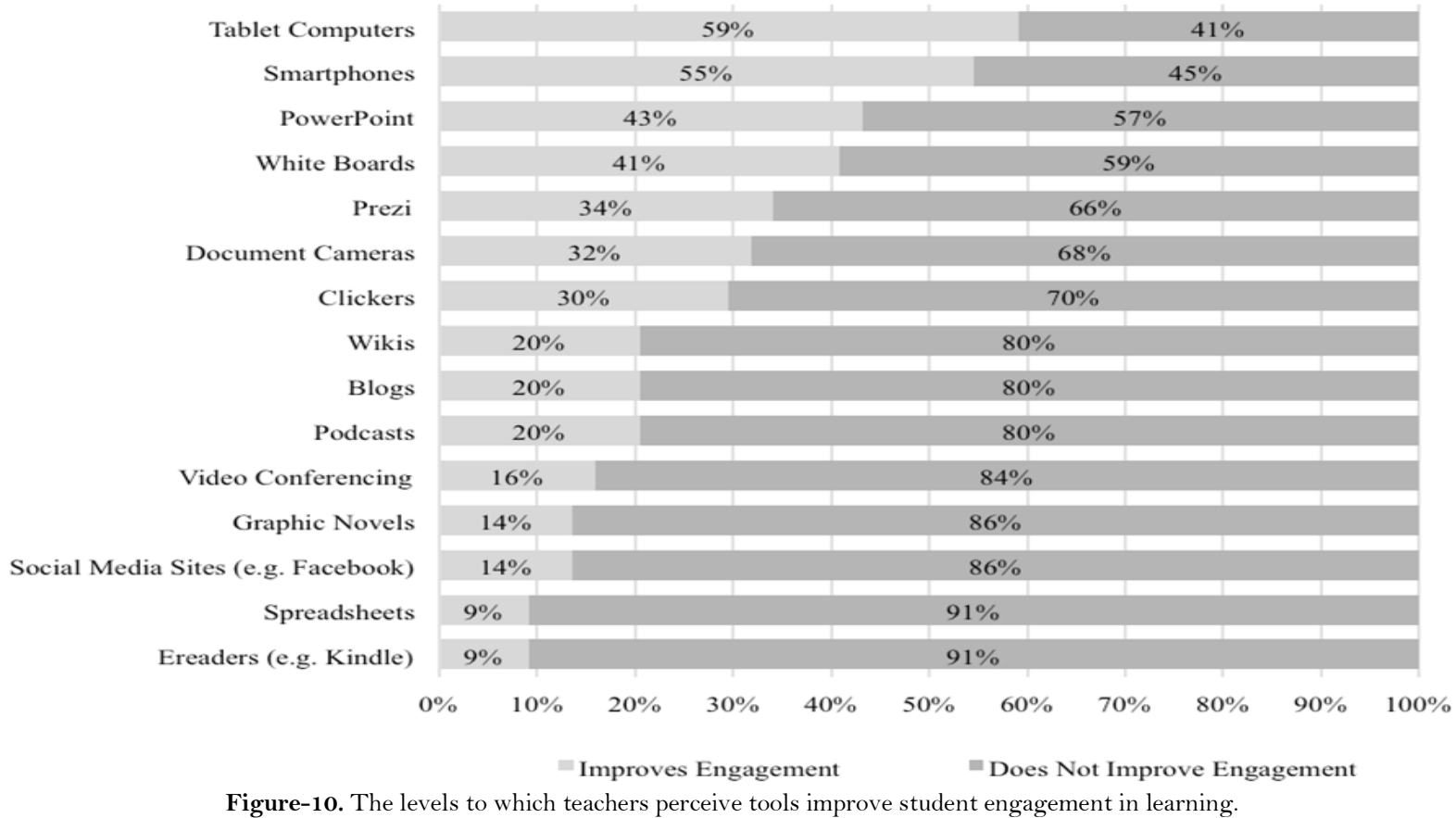


Many teachers expressed the belief that non-conventional tools increase student engagement in learning, for instance by stating that smartphones provide, "easy access, quick answers, [which is] engaging for students." Another teacher states "phones, tablets, and the internet options help with student engagement, making classroom management easier. Students feel teachers understand them when they understand how the newer technology works and use them regularly."

Conversely, another teacher shared a different perspective that suggests the lesson is about the content and not about the tools as they wrote, "All of the tools can be useful or challenging to incorporate well, so they are enhancing instruction - but just simply using a tool doesn't necessarily make it better teaching or better enhance student learning. A PowerPoint is nice, but a boring power point is still a boring lesson. The mode is less important than making sure they really understand the information and can apply it. Good teaching means figuring out how to use the tool to help the kids understand more/better."

Related to teacher perceptions of student engagement in learning, we next examined the teachers' perceptions of the tools as distractions to learning see Figure 11. The majority of teachers perceived smartphones as being distractions, and were divided on the question of social media. A minority of teachers did not perceive the balance of tools as being distractions.

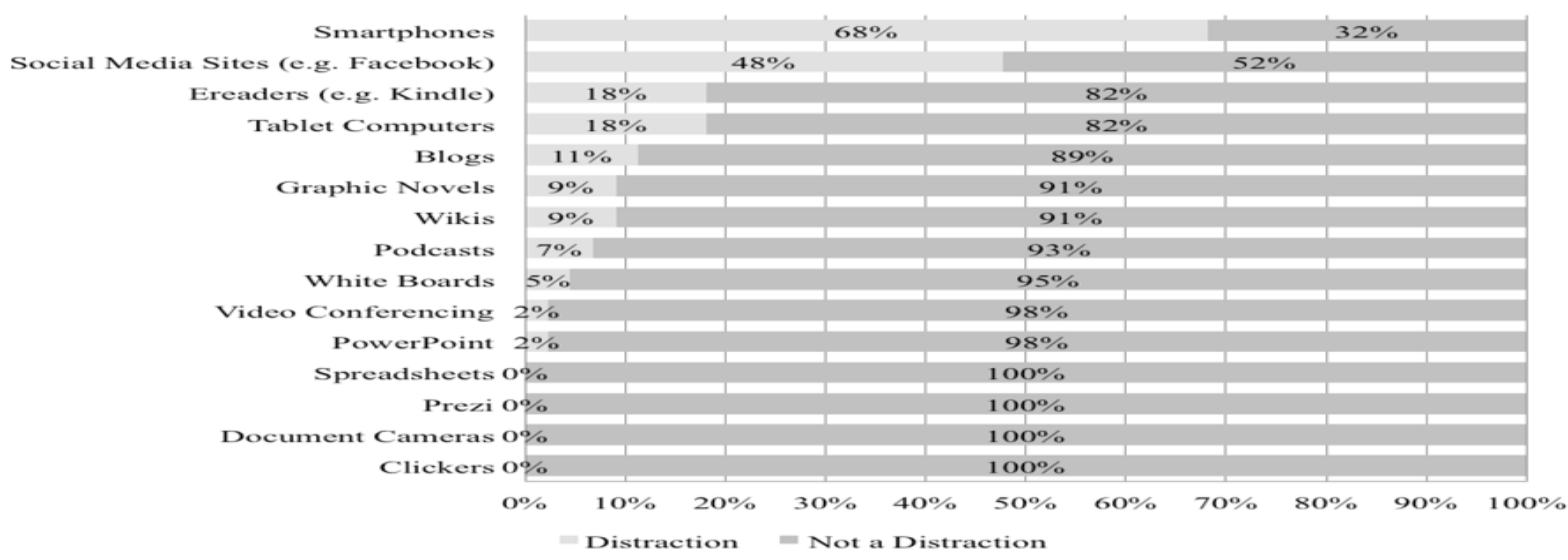

Figure-11. Levels of teacher perceptions of instructional tools as a distraction to student learning.

Through our analysis we found many teachers recognized the power of smartphones for learning, but struggled with having the appropriate approach for leveraging the devices for instruction as shared by one participant, "...you have to know how to use them and the different uses for these tools so that monitoring their use is easy. [For example consider] smartphones, if you know what a current apps look like at a glance you know exactly if students are on or off task with what you have asked them to be doing. If I am asking students to use their phones I require them to be flat on the desks so at a glance I can see if the entire table is on task or not." Similarly, another teacher shared, "The biggest challenge with using smartphones is that they can be used for non-educational purposes. It's hard to monitor when you have 40 students in your classroom and we can't allow students to use them on tests because they'll easily be able to cheat. Also, not all students have a smartphone so the teacher has to provide another method for them to do the same activity."

We completed our analysis of teacher perceptions of student uses of technology for learning by examining their concerns for student use of smartphones for learning. The primary concern was "equal access," and in contrast, the second concern was that the students could use the device at any time see Figure 12. None of the teachers selected "not familiar" and "no potential" as concerns for using smartphones as a tool for learning.

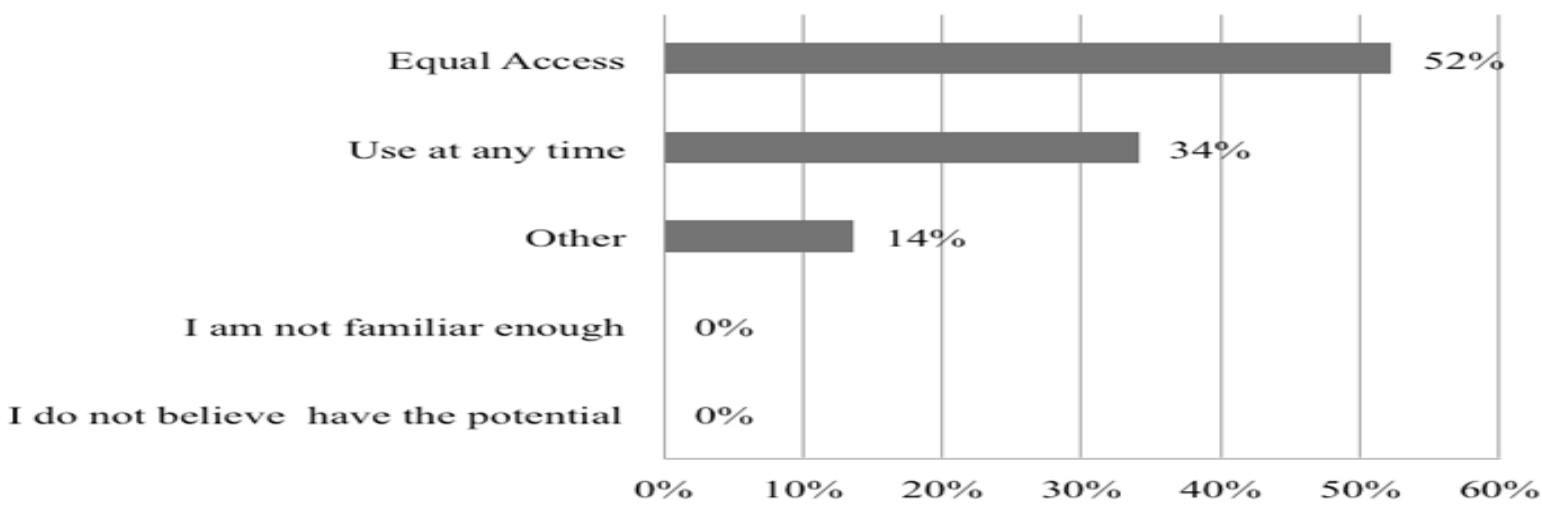

Figure-12. Teacher concerns with students' use of smartphone as a tool for learning. 
Although many of the teachers recognized the benefit of student use of smartphones for learning, they also shared several concerns such as equitable access. As one teacher shared, "Smart phones are great, very useful for finding out something quickly in class, but until every kid has access to the same thing, it isn't really fair to use it wide-spread as a main tool in the curriculum. Not every kid has a phone in every class, not every kid who has a phone has a smart phone. To say that a student must do some of their learning using a specific tool, especially if that tool is expensive, puts some kids at a disadvantage because not every kid's household can provide all the same tools." Offering another perception, this teacher shared concerns of smartphone as a distraction and not a learning tool as she wrote: “...students are accustomed to using them as toys, but not as tools. They quickly and frequently revert to the toy, even when they should be engaged in its use as a tool, with no way for the teacher to monitor it. Infrastructure also needs to be set up (money) to use effectively."

\subsection{Levels of Preparation}

Our final research question asked, What are teachers' levels of preparation for and experience with using nonconventional tools for instruction? To answer this question, we examined the items prompting the participants to share their levels of preparation to use the technology for instruction. Our analysis of the teachers' reported levels of knowledge of using the tools for teachings on a five-point scale ranging from "novice" (1) and "expert" (5) with the tools revealed they selected PowerPoint, whiteboards, and document cameras to be between competent and proficient see Figure 13. At the lower end of the knowledge scale we found that the teachers had novice to basis awareness levels of knowledge of wikis, clickers, and podcasts. The teachers rated the knowledge between basic and competent for the remainder of the tools.

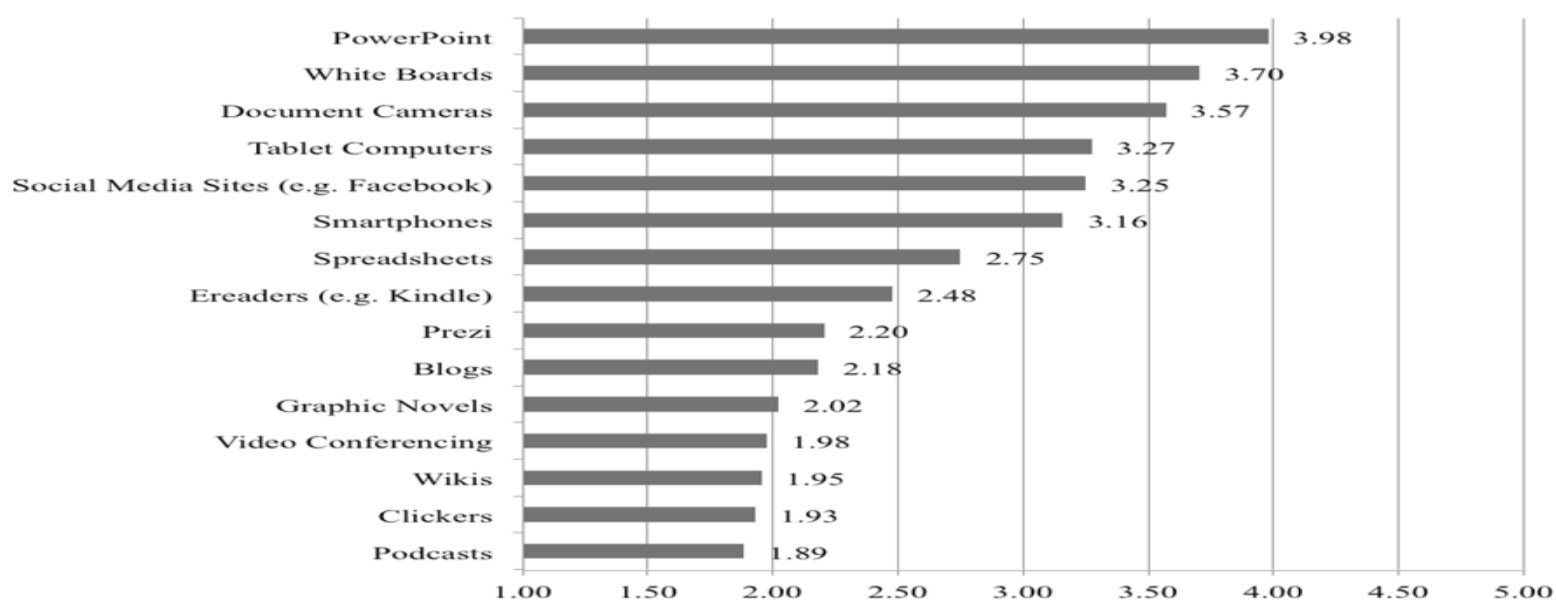

Figure-13. Teachers' level of knowledge using the tools for instruction.

In recognition of the need for teacher to be flexible in their use of technology for instruction one teacher shared, "In order to use them well, a teacher has to be experienced enough so that they can use the seamlessly. When networks go down, teachers have to have backup plans." However, it is likely that requires professional development that addresses the flexibility as another teacher shared, "Training and keeping up with the new stuff. Once we learn something it becomes outdated.” Further, for some, access often trumps the professional development of how to use the technology. As one teacher shared, "Availability and training. Both for the teacher and the student. I didn't see a tool mentioned in your study that couldn't have an academic use, but I can only use things that either I have available or my students do."

We found that the teachers had engaged in an average of 32 hours of professional development in the prior year. Our analysis of the teachers' engagement in non-conventional tools related professional development was based on a five-point scale ranging from "none" (1) to " $7+$ hours" (5). We found that the teachers had approximately 1-2 hours of professional development associated with PowerPoint and tablet computers see Figure 14. The teachers rated their levels of engagement in professional development for the remainder of the tools to be somewhere between "none" and perhaps 1 hour of professional development. 


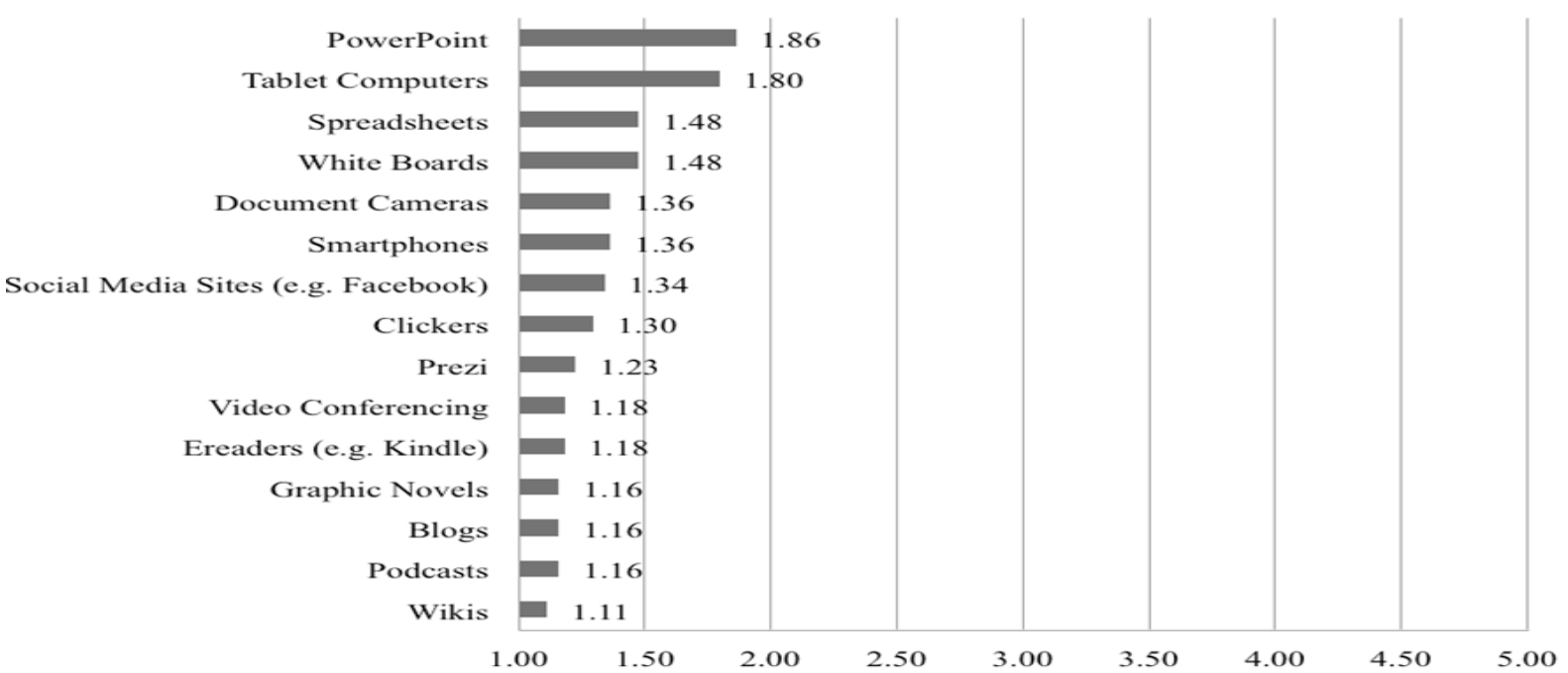

Figure-14. Levels of teacher professional development preparing them to use tools for instruction.

As one teacher explains, "If I could develop my curriculum, with someone who could help me integrate it into a statewide (at least district wide) technology I could really move on implementation. It is simply TOOOO time consuming to learn the "how" of integrating the curriculum into the technology." Reflective of many statements, this teacher simply shared, "I know that most students already know more about them than I do."

To determine where teachers go for information about using the tools for instruction, we examined their responses to our aligned item in which we asked teachers to select all options. Our analysis revealed that teachers seek information from other teachers and Internet at about twice the frequency of the third most selected source, the school district see Figure 15. The least frequent place teachers go for support for using non-conventional tools are school principals, colleges of education, professional journals, and popular media.

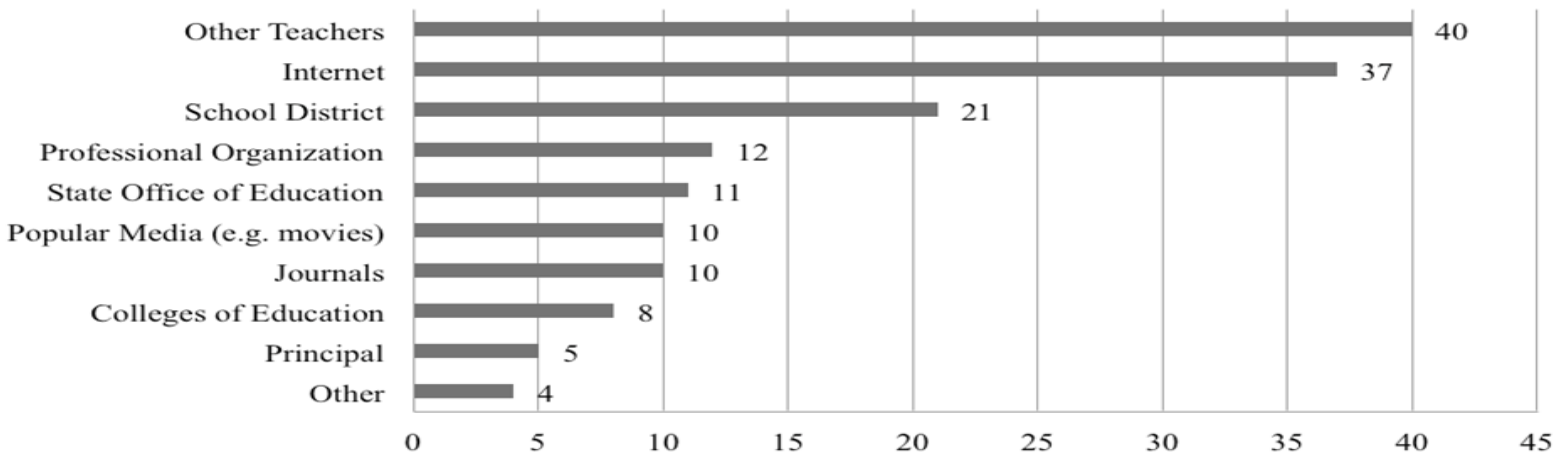

Figure-15. Where teachers go for guidance to support their use of tools for instruction.

Our review of the teachers' narratives responses to our qualitative items revealed professional development and support are an issue of concern that may hinder teacher capacity to effectively use the technology. As one teacher wrote, "The only challenges [that] come with technology is not having the support to get help with troubleshooting, not having the funds to get them, not really be applicable since technology is outdated so quickly, [and] the time it takes to train everyone."

\section{Discussion and Implications}

The goal of our research was to determine the current non-conventional instructional tool perceptions, practices, and needs of K-12 teachers. We found many consistencies with the prior studies, and exposed some unique conditions and areas of need. The rapidly changing landscape of technology and non-conventional tools in education provide warrant for ongoing monitoring of teachers' perceptions and needs.

Our finding that teachers tend to interact with non-conventional tools differently on a personal level than they do professionally suggests a need for more professional development. While the teachers may use technology constantly in both their personal and professional life, they have not been able to transfer their use to engaging their students in lessons that effectively apply or capitalize on the utility of the technology. The lack of transfer from personal to professional life suggests that the teachers lack models or ideas for how to effectively use and engage their students in using technology for learning. Thus, there is a need for 
professional development that engages beyond the traditional uses of the tools such as using technology as lecture tool (e.g., PowerPoint) to promote models of innovative technology use.

Similar to the lack of transfer of technology use from personal experiences to professional experiences, we found many teachers continued to use technology in a teacher centered manner. We posit that teachers continue to perceive that their role is to distribute knowledge and maintain control of the students rather than facilitate learning and inspire their students, which would explain why they maintain a teacher centered use of technology. Again, we argue that professional development modeling student centered use of technology would help address this situation. However, we also maintain that teacher-centered use of technology is reflective of teachers' lack of comfort with risk taking, as well as the ambiguity in the unpredictability associated with student engagement with the tools and the students' potential uses of the tools. Examining the relationship between teacher use of technology for student- centered learning and teacher levels of openminded thinking, risk taking, and tolerance for ambiguity is a potentially fruitful direction for future research.

Our research findings suggest that the lack of use of technology is not exclusively due to teacher choice or their preparation, as we found many teachers indicated that lack of support and access limited their abilities to effectively use technology for instruction. Thus, access to hardware, connectivity, speed and stability of the network, functionality of hardware, and to an array of software may be associated with teacher consideration of the use of technology in student-centered instruction. Yet, student access to smartphones and potentially other connected devices suggests that the focus on technology may not be fully warranted as justification for a lack of student-centered instruction. Further, there are multiple other non-conventional instructional tools that can be considered (e.g., graphic novels) as effective tools for student centered learning, which again suggests that access to certain technology may not fully explain the lack of student centered instruction.

Through our research we were able to document that teachers may perceive the challenges or potential negative issues of using non-conventional tools outweigh the perceived benefits. Our finding suggests that many teachers may not be willing to take the risks associated with using non-conventional tools and shifting their instruction to a student-centered approach. While the participants seemed to recognize that students are likely to gain from a more student-centered instructional approach, they communicated a teacher-focused perspective. Again, additional professional development may provide the teachers with the knowledge and models that could increase their propensity to consider more student-centered approaches to their instruction. Examining the content and processes of professional development in relationship to shifts in teacher studentcentered practices is a potentially fruitful direction for promoting changes in teacher curricular and instructional choices.

\section{Limitations}

Our first limitations is the cross sectional nature of our data collection, which only captured the teachers' perceptions and practices at one time. However, the combination of our quantitative and qualitative data reveals consistent relationships and perspectives which suggests that teacher practices and thoughts about the use of non-conventional tools is rather stable. Examining these perspective and practices at different times of the academic year and longitudinally are likely important directions for future research.

Secondly, our research was the collection of data from one region of the western United States. However, the consistency with the extant research suggests our findings were consistent. Gathering similar data in other areas of the United States and in other countries is likely to be an interesting direction for future research.

A third limitation is that our research focused broadly on the use of non-conventional tools; however, the use of non-conventional tools varies widely across disciplines. Future studies should examine how teachers integrate non-conventional tools across academic content-areas. Further research is needed to examine how science, mathematics, and engineering instruction technologies can be used to build and critique theories, to collect, analyze and interpret data, evaluate hypotheses through experimentation, and communicate scientific results. Moreover, more studies are needed evaluating teachers use non-conventional tools to engage students in model-based inquiry, peer collaboration, and problem-based learning through domain specific text, new literacies, and hyper-media environments. In the future, we plan to examine how non-conventional tools can be used to enhance content area competencies. Our research will involve developing and measuring teacher use of non-conventional tools to teach content-specific knowledge and processes.

The final limitation of our research is the self-report nature of our data and lack of opportunity to gain clarity of responses from the participants. However, we did collect rather frank answers with regard to teacher perceptions and uses of non-conventional tools, and the data were consistent, suggesting our data were representative of the thoughts and actions of the teachers. In our future research we will consider interviews and observations of teachers to gain a deeper understanding of the perceptions and practices with non-conventional tools.

\section{Conclusions}

As society continues to become more technologically reliant and integrated and new instructional tools emerge, there is warrant for continuing to monitor K-12 teachers' perceptions, practices, and needs associated 
with the tools. Though our research, we gathered a range of quantitative and qualitative data representative of teacher thoughts about the use of non-conventional tools and how they were using the tools. Our data reflect little shifts in teacher practice over the past 20 years, and the development of new struggles, as student access to personal technology and expectations for using non-conventional instructional tools has increased dramatically. Our research suggests there is a tremendous need for a shift in the nature of professional development to prepare teachers with knowledge of new ideas for teaching and learning that focuses less on how the tools function and more on innovative practices. Non-conventional tools can have a powerful impact on how students acquire domain specific information. Our research has confirmed not only the need to continue to monitor teacher perceptions and practice, but also the necessity to adjust professional development to meet their shifting needs.

\section{References}

Abrami, P. C., Poulsen, C., \& Chambers, B. (2004). Teacher motivation to implement an educational innovation: Factors differentiating users and non-users of cooperative learning. Educational Psychology, 24(2), 201-216.

Baylor, A. L., \& Ritchie, D. (2002). What factors facilitate teacher skill, teacher morale, and perceived student learning in technology-using classrooms? Computers \& Education, 39(4), 395-414.

Becker, H. (1999). Internet use by teachers: Conditions of professional use and teacher-directed student use. Irvine, CA: Center for Research on Information Technology and Organizations.

Black, R. W. (2008). Just don't call them cartoons: The new literacy spaces of anime, manga and fanfiction. In J.Coiro, M.Knobel, C.Lankshear, \& D.Leu (Eds.), Handbook of Research on New Literacies. New York: Lawrence Erlbaum Associates.

Blanchard, M. R., Southerland, S. A., \& Granger, E. M. (2009). No silver bullet for inquiry: Making sense of teacher change following an inquiry-based research experience for teachers. Science Education, 93(2), 322-360.

Borko, H., \& Putnam, R. T. (1995). Expanding a teacher's knowledge base: A cognitive psychological perspective on professional development. In T. R. Guskey \& M. Huberman (Eds.), Professional Development in Education: New Paradigms \& Practices. New York: Teachers College Press.

Brinkerhoff, J. (2006). Effects of a long-duration professional development academy on technology skills, computer selfefficacy, and technology integration beliefs and practices. International Society for Technology in Education, 39(1), $22-43$.

Briscoe, C. (1991). The dynamic interactions among beliefs, role metaphors, and teaching practices: A case study of teacher change. Science Education, 75(2), 185-199.

Brown, D., \& Warschauer, M. (2006). From the university to the elementary classrooms: Students' experiences in learning to integrate technology in instruction. Journal of Technology and Teacher Education, 14(3), 599-62 1.

Browns, E. T., Karp, K., Petrosko, J., Jones, J., Beswick, G., Howe, C., \& Zwanzig, K. (2007). Crutch or catalyst: Teachers' beliefs and practices regarding calculator use in mathematics instruction. School Science and Mathematics, 107(3), $102-116$.

Burns-Sardone, N. (2014). Making the case for BYOD instruction in teacher education. Issues in Informing Science and Information Technology, $11(1)$, 191-201.

Clark, J. S. (2014). Teaching historical agency: Explicitly connecting past and present with graphic novels. Social Studies Research and Practice, 9(3), 66-80.

Coiro, J., Knobel, M., Lankshear, C., \& Leu, D. (2008). Central issues in new literacies and new literacies research. In J.Coiro, M.Knobel, C.Lankshear, छ D.Leu (Eds.), Handbook of Research on New Literacies. New York: Lawrence Erlbaum Associates.

Cuban, L., Kirkpatrick, H., \& Peck, C. (2001). High access and low use of technologies in high school classrooms: Explaining an apparent paradox. American Educational Research Journal, 38(4), 813-834.

Ertmer, P. A. (1999). Addressing first-and second-order barriers to change: Strategies for technology integration. Educational Technology Research and Development, 47(4), 47-61.

Ertmer, P. A., \& Ottenbreit-Leftwich, A. T. (2010). Teacher technology change: How knowledge, confidence, beliefs, and culture intersect. Journal of Research on Technology in Education, 42(3), 255-284.

Fabry, D. L., \& Higgs, J. R. (1997). Barriers to the effective use of technology in education: Current status. Journal of Educational Computing Research, 17(4), 385-395.

Funkhouser, B. J., \& Mouza, C. (2013). Drawing on technology: An investigation of pre-service teacher beliefs in the context of an introductory educational technology course. Computers \& Education, 6(2), 271-285.

Goldberg, A., Russell, M., \& Cook, A. (2003). The effect of computers on student learning: A meta-analysis of studies from 1992 to 2002. Journal of Technology, Learning, and Assessment, 2(1), 1-51.

Gregoire, M. (2003). Is it a challenge or a threat? A dual-process model of teachers' cognition and appraisal processes during conceptual change. Educational Psychology Review, 15(2), 147-179.

Groff, K., \& Mouza, C. (2008). A framework for addressing challenges to classroom technology use. Association for the Advancement of Computing in Education Journal, 16(1), 21-46.

Gumbo, M., Makgato, M., \& Helene, M. (2012). The impact of in-service technology training programmers on technology teachers. Journal of Technology Studies, 38(1), 23-33.

Guskey, T. R. (2002). Professional development and teacher change. Teachers and Teaching, 8(3), 381-391.

Hirumi, A. (2002). Student-centered, technology-rich learning environments (SCenTRLE): Operationalizing constructivist approaches to teaching and learning. Journal of Technology and Teacher Education, 1O(4), 497-538.

Hixon, E., \& Buckenmeyer, J. (2009). Revisiting technology integration in schools: Implications for professional development. Computers in the Schools, 26(2), 130- 146

Hughes, J. (2005). The role of teacher knowledge and learning experiences in forming technology-integrated pedagogy. Journal of Technology and Teacher Education, 13(2), 277-302. 
Kanter, R. M. (2000). When a thousand flowers bloom: Structural, collective, and social conditions for innovation in organization. In R. Swedberg (Ed.) Entrepreneurship: The Social Science View (pp. 167-210). Oxford, UK: Oxford University Press.

Lankshear, C., \& Knobel, M. (2006). New literacies: Everyday practices and classroom learning (2nd ed.). Maidenhead \& New York: Open University Press.

Lawless, K. A., \& Pellegrino, J. W. (2007). Professional development in integrating technology into teaching and learning: Knowns, unknowns, and ways to pursue better questions and answers. Review of Educational Research, 77(4), 575614.

Levin, T., \& Wadmany, R. (2008). Teachers' views on factors affecting effective integration of information technology in the classroom: Developmental scenery. Journal of Technology and Teacher Education, 16(2), 233-263.

Nadelson, L. S., Bennett, D., Gwilliam, E., Howlett, C., Oswalt, S., \& Sand, J. (2013). The intersection of preservice teachers' confidence, perceptions, and ideas for using instructional technology for teaching and learning. International Journal of Higher Education, 2(4), 77-90.

Nadelson, L. S., Briggs, P., Hammons, D., Bubak, K., \& Sass, M. (2012). The tension between teacher accountability and flexibility: The paradox of standards-based reform. Teacher Education and Practice, 25(2), 196-220.

Nadelson, L. S., Seifert, A. L., \& Sias, C. (2015). To change or not to change: indicators of K-12 teacher engagement in innovative educational practices. International Journal of Innovation in Education, 3(1), 45-61.

Nadelson, L. S., Sias, C. M., \& Seifert, A. L. (2016). Challenges for integrating engineering into the K-12 curriculum: Indicators of K-12 teachers' propensity to adopt educational innovations. Paper presented at the Proceedings of the American Society of Engineering Education Annual Conference and Exposition, New Orleans, LA.

Niess, M. L. (2005). Preparing teachers to teach science and mathematics with technology: Developing a technology pedagogical content knowledge. Teaching and Teacher Education, 21(5), 509-523.

Ottenbreit-Leftwich, A. T., Glazewski, K. D., Newby, T. J., \& Ertmer, P. A. (2010). Teacher value beliefs associated with using technology: Addressing professional and student needs. Computers $\mathcal{E}^{2}$ Education, 55(3), 132 1-1335.

Palak, D., \& Walls, R. T. (2009). Teachers' beliefs and technology practices: A mixed-methods approach. Journal of Research on Technology in Education, 41(4), 417-441.

Rakes, G. C., Fields, V. S., \& Cox, K. E. (2006). The influence of teachers' technology use on instructional practices. Journal of Research on Technology in Education, 38(4), 409-424.

Roblyer, M., McDaniel, M., Webb, M., Herman, J., \& Witty, J. V. (2010). Findings on Facebook in higher education: A comparison of college faculty and student uses and perceptions of social networking sites. The Internet and Higher Education, 13(3), 134-140.

Russell, M., Bebell, D., O'Dwyer, L., \& O'Connor, K. (2003). Examining teacher technology use implications for preservice and inservice teacher preparation. Journal of Teacher Education, 54(4), 297-310.

Ryan, T., \& Bagley, G. (2015). Nurturing the integration of technology in education. Journal of Theory \& Practice in Education, 11(1), 33-50.

Scott, S. G., \& Bruce, R. A. (1994). Determinants of innovative behavior: A path model of individual innovation in the workplace. Academy of Management Journal, 37(3), 580-607.

Subramaniam, K. (2007). Teachers' mindsets and the integration of computer technology. British Journal of Educational Technology, 38(6), 1056-1071.

Thurlings, M., Evers, A. T., \& Vermeulen, M. (2015). Toward a model of explaining teachers' innovative behavior a literature review. Review of Educational Research, 85(3), 430-471.

Tondeur, J., Van Braak, J., Sang, G., Voogt, J., Fisser, P., \& Ottenbreit-Leftwich, A. (2012). Preparing pre-service teachers to integrate technology in education: A synthesis of qualitative evidence. Computers \& Education, 59(1), 134-144.

Warschauer, M., \& Ware, P. (2008). Learning, change, and power: Competing frames of technology and literacy. In J. Coiro, M. Knobel, C. Lankshear, \& D. J. Leu (Eds.), Handbook of Research on New Literacies. New York: Routledge.

Windschitl, M., \& Sahl, K. (2002). Tracing teachers' use of technology in a laptop computer school: The interplay of teacher beliefs, social dynamics, and institutional culture. American Educational Research Journal, 39(1), 165-205.

Wozney, L., Venkatesh, V., \& Abrami, P. C. (2006). Implementing computer technologies: Teachers' perceptions and practices. Journal of Technology and Teacher Education, 14(1), 173-207. 